\title{
The application of the $n$-alkane technique for estimating the composition of diets consumed by equines and cattle feeding on upland vegetation communities
}

\author{
L.M.M. Ferreira $^{\mathrm{a}, *}$, U. Garcia $^{\mathrm{b}}$, M.A.M. Rodrigues ${ }^{\mathrm{a}}$, \\ R. Celaya ${ }^{b}$, A. Dias-da-Silva ${ }^{a}$, K. Osoro ${ }^{b}$ \\ ${ }^{a}$ CECAV-Departamento de Zootecnia, Universidade de Trás-os-Montes e Alto Douro, \\ P.O. Box 1013, 5001-801 Vila Real, Portugal \\ b SERIDA - Servicio Regional de Investigación y Desarrollo Agroalimentario, \\ P.O. Box 13, 33300 Villaviciosa, Asturias, Spain
}

Received 14 June 2006; received in revised form 31 October 2006; accepted 7 November 2006

\begin{abstract}
The application of $n$-alkanes as faecal markers to estimate diet composition of equines and cattle was studied. Twelve mature crossbreed mares ( $385 \pm 47 \mathrm{~kg}$ live weight $-\mathrm{LW})$ and six adult non-lactating cows $(499 \pm 36 \mathrm{~kg} \mathrm{LW})$ of Asturiana de los Valles breed were divided in groups of three animals $(\mathrm{H} 1$, $\mathrm{H} 2, \mathrm{H} 3$ and $\mathrm{H} 4$ in equines and $\mathrm{C} 1$ and $\mathrm{C} 2$ in cattle) and housed in individual stalls. Animals received a daily total amount of $1.0 \mathrm{~kg} \mathrm{DM} / 100 \mathrm{~kg} \mathrm{LW}$ of different experimental diets composed of herbaceous (Lolium perenne L.) and woody species (Ulex gallii Planchon and heather: Erica spp. and Calluna vulgaris $\mathrm{L}$.). Diet composition varied among treatments: $\mathrm{H} 1$ and $\mathrm{C} 1-L$. perenne as sole component; $\mathrm{H} 2$ and $\mathrm{C} 2-L$. perenne $(0.70)$ and heather $(0.30) ; \mathrm{H} 3-L$. perenne $(0.70)$ and $U$. gallii $(0.30) ; \mathrm{H} 4-$ L. perenne (0.40), heather (0.30) and $U$. gallii $(0.30)$.

Diet composition was estimated from the alkane concentrations $\left(\mathrm{C}_{27}, \mathrm{C}_{29}, \mathrm{C}_{31}\right.$ and $\left.\mathrm{C}_{33}\right)$ in diet and faeces by least-squares procedures. Furthermore, the effect of using different sets of alkane

Abbreviations: ADF, acid detergent fibre; AFR, alkane faecal recovery; CP, crude protein; DM, dry matter; DMD ap, apparent dry matter digestibility; F, total faecal output; I, intake; LW, live weight; NDF, neutral detergent fibre

* Corresponding author. Tel.: +351 259350421; fax: +351259325058.

E-mail address: 1mf@utad.pt (L.M.M. Ferreira).
\end{abstract}


faecal recovery, without no faecal recovery correction (R1), applying mean diet faecal recoveries (R2) or applying mean faecal recoveries across all diets (R3) was evaluated. The results showed that in equines the alkane faecal recovery was unrelated with carbon chain length. In contrast, in cattle, the alkane faecal recoveries increased with alkane chain length. The results obtained in equines suggested a negative association between diet digestibility (ranging from 0.39 to 0.58 ) and alkane faecal recoveries (ranging from 0.84 to 1.08 ) for the alkanes $\mathrm{C}_{27}\left(r^{2}=0.701, \mathrm{P}<0.001\right), \mathrm{C}_{29}\left(r^{2}=0.580\right.$, $\mathrm{P}<0.01), \mathrm{C}_{31}\left(r^{2}=0.604, \mathrm{P}<0.01\right)$ and $\mathrm{C}_{33}\left(r^{2}=0.742, \mathrm{P}<0.001\right)$. Accurate diet composition estimates were obtained in equines using alkane faecal concentrations corrected or not for their incomplete faecal recovery.

The results obtained in this study confirmed the usefulness of the $n$-alkane markers to estimate diet composition of equines and cattle grazing these type vegetation communities with very different components. However, in cattle these diet composition markers needed proper adjustment of their faecal concentrations prior to their application.

(C) 2006 Elsevier B.V. All rights reserved.

Keywords: Herbivores; $n$-Alkane markers; Heathland

\section{Introduction}

In many mountain and marginal areas around the world equines graze together with sheep, cattle, goats and also with wild herbivores in a multi-species herd, with different levels of competition between them. One of the main objectives of landscape conservation is the maintenance of high levels of biodiversity. It is clear that biodiversity is highly dependent on the management of natural resources (Rook et al., 2004). Therefore it is essential to know the diet selection of the herbivores in order to establish the appropriate type of herd (proportion of different animal species) and management to achieve high levels of biodiversity and the sustainability of livestock and ecosystems.

Different studies have shown the differences in grazing behaviour between cattle and horses grazing in different conditions such as Pyrenees (Aldezabal, 2001) and Savannah (Lechner-Doll et al., 1995). The ability of equines for grazing a shorter grass than that needed by cattle for maintenance, and also the intake capacity of equines for shrub species as Ulex spp. when the availability of grassy species is very low (Osoro et al., 2005) made equines highly competitive against cattle. The competition for the management of grassy areas seems to be very high. However, the complementarily for the management of marginal vegetation communities dominated by certain woody species as Ulex spp. could also be high. Sequential grazing could be one of the management strategies for grass-woody vegetation communities. Nevertheless, we need to know the behaviour of these two herbivores species under certain vegetation conditions and the level of utilization and intake.

The objective of the present work was to validate the $n$-alkane technique to estimate diet composition in equines and cattle feeding with herbaceous (Lolium perenne L.) and woody species. For this purpose, different diets composed of herbaceous (L. perenne L.) and woody species (Ulex gallii Planchon and heather: Erica spp., Calluna vulgaris L.) were offered to horses and cows in a metabolic crate study in order to allow total faecal collection and sampling of feeds. 


\section{Materials and methods}

\subsection{Experimental site and design}

This study was conducted at Carbayal Research Station, situated at 900-1000 m above sea level, at San Isidro's Mountain, Asturias, Spain (longitude $-6^{\circ} 53^{\prime}$, latitude $43^{\circ} 21^{\prime}$ ), where the vegetation is dominated by a mosaic of gorse-heathland interspersed with small areas of improved pastures (Lolium perenne L.).

The experiment (11 days) was carried out between November and December of 2004, at the end of the grazing and vegetation growth season, and consisted of a 7-day period for adaptation of the animals to the diets and experimental conditions followed by 4 days of faeces collection. Samples of each of the diet components were collected daily for chemical and alkane analysis (from day 1 to 11 ) and sub-sampled for dry matter (DM) determination.

During the study, daily total faecal output was recorded individually. For total faecal output determination, faeces were removed from the floor, retained in individual containers and weighted. After homogenization, one sample of total faeces from each animal was collected for DM determination and another sample was prepared for alkane analysis.

Prior to the trial, the animals were grazing on the type of vegetation described for these marginal areas, which was used in the experimental diets.

\subsection{Animals and diets}

Twelve mature crossbreed mares (385 $\pm 47 \mathrm{~kg}$ live weight - LW) and six adult nonlactating cows $(499 \pm 36 \mathrm{~kg} \mathrm{LW})$ of Asturiana de los Valles breed, housed individually in metabolic crates, were randomly distributed in groups of three animals for each animal species ( $\mathrm{H} 1, \mathrm{H} 2, \mathrm{H} 3$ and $\mathrm{H} 4$ for horses and $\mathrm{C} 1$ and $\mathrm{C} 2$ for cows). $\mathrm{H} 1$ and $\mathrm{C} 1$ received a diet composed only by ryegrass (Lolium perenne $\mathrm{L}$.) and $\mathrm{H} 2$ and $\mathrm{C} 2$ were fed on a diet composed of ryegrass $(0.70)$ and heather $(0.30)$. H3 was fed on a diet of ryegrass $(0.70)$ and gorse (Ulex gallii Planchon, 0.30$)$ and $\mathrm{H} 4$ received ryegrass $(0.40)$, gorse $(0.30)$ and heather (0.30). During the study animals were offered a daily total amount of $1.0 \mathrm{~kg} \mathrm{DM} / 100 \mathrm{~kg} \mathrm{LW}$. The species composition of the diets reflected the grazing behaviour of cattle and equines on these vegetation communities observed in previous studies (Osoro et al., 2005).

Gorse was only included as a diet component in the equine treatments (H3 and H4), since previous studies showed that this plant species is rejected by cattle (Osoro et al., 2003). Gorse is a thorny legume, characteristic of these marginal vegetation communities, mixed with Erica spp. and C. vulgaris, which can be selected by equines in situations where the grass availability is low.

Freshly cut vegetation components (ryegrass and green shoots of gorse and heather) were harvested daily from random sites within the experimental field and were offered in individual mangers along the day in an attempt to prevent loss of diet components. The botanical composition of the vegetation component called "heather" represents the field proportions of different plant species of heathland, namely Erica umbellata L., Erica cinerea L. and Calluna vulgaris L., in this experimental period. 


\subsection{Chemical analysis}

Samples of diet components (ryegrass, gorse and heather) and faeces were immediately dried on the day of collection, using a forced-air oven at $60^{\circ} \mathrm{C}$ for $72 \mathrm{~h}$, for DM determination. The samples for alkane analyses were immediately frozen at $-20^{\circ} \mathrm{C}$ and then freeze-dried and milled through a $1 \mathrm{~mm}$ screen.

Ground samples were analyzed for ash (no. 942.05, AOAC, 1990) and total N as Kjeldahl $\mathrm{N}$ (no. 954.01, AOAC, 1990). Crude protein (CP) was calculated as Kjeldahl $\mathrm{N} \times 6.25$. Neutral detergent fibre (NDF) and acid detergent fibre (ADF) were analysed by the method of Van Soest et al. (1991) and expressed inclusive of residual ash. Sodium sulfite and heat stable amylase were not added. Lignin ( $\mathrm{sa}$ ) was determined by solubilization of cellulose with sulphuric acid (Van Soest et al., 1991). Hemicellulose and cellulose were calculated as the difference between NDF and ADF and ADF and lignin (sa), respectively.

\subsection{Alkane analysis}

Alkane concentration of individual samples of diet components and faeces were analysed in duplicate according to the methods of Mayes et al. (1986), modified by Oliván and Osoro (1999).

The first stage involved the saponification of $0.5 \mathrm{~g}$ of faeces or $1.5 \mathrm{~g}$ of vegetation components for $14 \mathrm{~h}$ in $7 \mathrm{ml}$ ethanolic $\mathrm{KOH} 1 \mathrm{M}$ at $90^{\circ} \mathrm{C}$ in a dry-block heater (Techne DB-3, Techne Ltd., Duxford, Cambridge, UK). Afterwards, a hot extraction was performed with $n$-heptane at $65^{\circ} \mathrm{C}$ (Oliván and Osoro, 1999). After the extraction, the sample was passed through a silica-gel column (bed volume $5 \mathrm{ml}$ ), to separate the alkanes from pigments, sterols and alcohols. Samples eluted from the columns were evaporated to dryness, and then redissolved in $500 \mu \mathrm{l}$ of heptane for chromatographic analysis.

Quantification of the alkanes was carried out by gas chromatography, using a VARIAN $3400 \mathrm{GC}$, equipped with flame ionisation detector (FID), an 8200 autosampler and a temperature-programmable injector.

Alkane extracts were injected $(0.5 \mu \mathrm{l})$ by on-column injection on a 15-metre column DB-1 megabore of $0.530 \mathrm{~mm}$ internal diameter and $1.5 \mu \mathrm{m}$ film thickness. Helium was used as carrier gas at a constant flow of $15 \mathrm{ml} / \mathrm{min}$. Gradients of temperature were used for the injector $\left(80^{\circ} \mathrm{C}\right.$ for $0.2 \mathrm{~min} ; 200^{\circ} \mathrm{C} / \mathrm{min}$ to $\left.380^{\circ} \mathrm{C}\right)$ and the column $\left(200^{\circ} \mathrm{C}\right.$ for $1 \mathrm{~min} ; 6^{\circ} \mathrm{C} / \mathrm{min}$ to $300^{\circ} \mathrm{C} ; 6 \mathrm{~min}$ at $300^{\circ} \mathrm{C}$ ). The detector oven was maintained at $350^{\circ} \mathrm{C}$.

Gas chromatographic method was calibrated with a standard solution containing a mixture of synthetic alkanes (from $\mathrm{C}_{23}$ to $\mathrm{C}_{36}$ ) with concentrations similar to those found in extracts. The response factors for individual alkanes were calculated from peak areas and the known concentrations. The detector response to different concentrations of each solute was linear throughout the range of concentrations found in the injected samples. Alkane concentrations were quantified relative to known amounts of the internal standards $\mathrm{C}_{22}$ (n-docosane) and $\mathrm{C}_{34}$ (n-tetratriacontane), added at the beginning of the extraction process. The use of two internal standards enabled the evaluation of the effectiveness of the extraction process and the correction of the peak areas for any discrimination detected during the solvent-extraction step (Oliván and Osoro, 1999). 


\subsection{Calculations}

The faecal recovery of each $n$-alkane (AFR) was calculated for each animal as the proportion of alkane consumed in the diet which was recovered in the faeces (Eq. (1)):

$$
\mathrm{AFR}_{i}=\frac{F \times F_{i}}{R \times R_{i}+G \times G_{i}+H \times H_{i}}
$$

where $\mathrm{AFR}_{i}$ is the faecal recovery of $i$ alkane, $F$ is the faecal DM output, $F_{i}$ the faecal concentration of the $i$ alkane. $R, G$ and $H$ are the mean amounts of the diet components $\mathrm{R}$ (ryegrass), $\mathrm{G}$ (gorse) and $\mathrm{H}$ (heather) consumed over the entire period and $R_{i}, G_{i}$ and $H_{i}$ the $i$ alkane concentrations in $\mathrm{R}, \mathrm{G}$ and $\mathrm{H}$, respectively.

Individual diet composition estimates were obtained using an optimization procedure which minimises the sum of squared discrepancies between the actual (A) alkane proportions in faeces (adjusted for the incomplete faecal recoveries) and the estimated (E) proportions (different combinations of diet components), as follows (Salt et al., 1994; Oliván et al., 1999):

$$
\sum_{i=1}^{n}[A-E]^{2}=\sum_{i=1}^{n}\left[\frac{\mathrm{F} i}{\mathrm{~F} t}-\frac{r \times \mathrm{R} i+h \times \mathrm{H} i+g \times \mathrm{G} i}{r \times \mathrm{R} t+h \times \mathrm{H} t+g \times \mathrm{G} t}\right] \text { minimal }
$$

where $r, h$ and $g$ are the proportions of components $\mathrm{R}, \mathrm{H}$ and $\mathrm{G}$ in the diet; $F i, \mathrm{R} i, \mathrm{H} i$ and $\mathrm{G} i$ are the concentrations of alkane $i$ in faeces (corrected for incomplete faecal recovery) and components $\mathrm{R}, \mathrm{H}$ and $\mathrm{G} ; \mathrm{F} t, \mathrm{R} t, \mathrm{H} t$ to $\mathrm{G} t$ are total alkane concentrations in faeces and components $\mathrm{R}, \mathrm{H}$ and $\mathrm{G}$. For diet composition calculations it was assumed that all animals had potential access to all vegetation components (L. perenne, heather and U. gallii) in order to test the capability of the alkane technique in estimating feeds which are not part of the diet but are available for consumption.

Diet composition calculations were performed using only the long chain alkanes $\left(\mathrm{C}_{27}\right.$, $\mathrm{C}_{29}, \mathrm{C}_{31}$ and $\mathrm{C}_{33}$ ) with higher concentration in diet and faeces applying three different alkane faecal recovery corrections:

- R1, without any correction for incomplete faecal recovery;

- R2, alkane faecal concentrations were corrected using the mean recovery of the dietary treatment that the animal belonged to;

- R3, alkane faecal concentrations were corrected using the mean recovery across all experimental diets.

Apparent in vivo dry matter digestibility $\left(\mathrm{DMD}_{\mathrm{ap}}\right)$ was calculated from total faecal collection using the equation $\mathrm{DMD}_{\text {ap }}=(I-\mathrm{F}) / I$, where $I$ is the total intake and $F$ the total faecal output.

\subsection{Statistical analysis}

Statistical analyses were carried out using the JMP program (2003). The effect of treatment, $n$-alkane $\left(\mathrm{C}_{27}, \mathrm{C}_{29}, \mathrm{C}_{31}\right.$ and $\left.\mathrm{C}_{33}\right)$ and their interaction on the recovery of the alkanes in faeces of each animal species (equines and cattle) was examined by two-way analysis 
of variance (ANOVA). The effect of diet digestibility on the AFR was analysed by linear regression. The effect of using different sets of AFR (R1, R2 and R3) on the estimates of each individual vegetation component within each treatment $(\mathrm{H} 1, \mathrm{H} 2, \mathrm{H} 3, \mathrm{H} 4, \mathrm{C} 1$ and $\mathrm{C} 2)$ was analysed by one-way analysis of variance (ANOVA). Within each diet, all the estimates of individual components were compared using the Tukey test $(\mathrm{P}<0.05)$.

\section{Results and discussion}

The chemical composition of the vegetation components offered to the animals in this study is summarized in Table 1. Cell wall components represented the highest fraction in all feeds. The browse vegetation components (heather and gorse) showed high levels of lignin (sa). The level of CP presented by $U$. gallii was higher than that presented by heather. As stated before, gorse is a thorny legume, characteristic of these marginal vegetation communities and presents high levels of CP (217 g CP/kg DM, Ferreira et al., 2005) in early stages of development, decreasing to a minimum of $87 \mathrm{~g} \mathrm{CP} / \mathrm{kg} \mathrm{DM}$ in the end of the grazing season (Osoro et al., in press). Evident differences between the woody species (heather and $U$. gallii) were also observed in the cellulose content.

The $n$-alkane content of the plant species used as possible diet components in this study is showed in Table 2. The concentrations of $\mathrm{C}_{22}$ and $\mathrm{C}_{34}$ are not shown as they were used as internal standards in GC analyses.

The alkane profile varied between plant species and was similar to those found for these vegetation species in previous reports (Oliván and Osoro, 1997; Dove and Mayes, 2005; Ferreira et al., 2005, 2006). The odd-chain alkanes comprised the highest fraction in the vegetation components, varying between 0.87 and 0.93 of the total alkane concentration. The predominant alkanes in the L. perenne and heather were $\mathrm{C}_{29}, \mathrm{C}_{31}$ and $\mathrm{C}_{33}$.

Heather was the plant species with the highest concentrations in all alkanes, except for $\mathrm{C}_{25}$. The alkane concentrations presented by $U$. gallii were higher than $10 \mathrm{mg} / \mathrm{kg} \mathrm{DM}$ for the alkanes $\mathrm{C}_{27}, \mathrm{C}_{28}, \mathrm{C}_{29}$ and $\mathrm{C}_{31}$. Alkanes with concentrations lower than $10 \mathrm{mg} / \mathrm{kg}$ DM were observed in the L. perenne $\left(\mathrm{C}_{23}, \mathrm{C}_{24}, \mathrm{C}_{26}, \mathrm{C}_{28}, \mathrm{C}_{32}\right.$ and $\left.\mathrm{C}_{36}\right)$ and heather $\left(\mathrm{C}_{23}, \mathrm{C}_{24}, \mathrm{C}_{25}, \mathrm{C}_{26}\right.$ and $\mathrm{C}_{36}$ ). The very low concentration of alkanes is important as it could limit their use in diet composition calculations. In this study, we decided to use only the alkanes $\mathrm{C}_{27}, \mathrm{C}_{29}, \mathrm{C}_{31}$ and

Table 1

Chemical composition ( $\mathrm{g} / \mathrm{kg} \mathrm{DM}$ ) of the diet components consumed by the animals during the study

\begin{tabular}{lccc}
\hline & L. perenne & Heather & U. gallii \\
\hline Organic matter & $934 \pm 4.1$ & $976 \pm 8.3$ & $975 \pm 1.5$ \\
Crude protein & $163 \pm 11.2$ & $53 \pm 4.6$ & $93 \pm 6.7$ \\
NDF & $532 \pm 24.8$ & $628 \pm 37.1$ & $681 \pm 23.5$ \\
ADF & $269 \pm 15.5$ & $519 \pm 23.9$ & $520 \pm 19.9$ \\
Lignin (sa) & $53 \pm 8.3$ & $341 \pm 64.3$ & $217 \pm 6.4$ \\
Cellulose & $205 \pm 26.3$ & $178 \pm 57.9$ & $303 \pm 20.9$ \\
Hemicellulose & $263 \pm 17.5$ & $121 \pm 7.5$ & $161 \pm 11.5$ \\
\hline
\end{tabular}

NDF: neutral detergent fibre.

ADF: acid detergent fibre. 
Table 2

Mean ( \pm standard deviation) $n$-alkane content $(\mathrm{mg} / \mathrm{kg} \mathrm{DM})$ of the plant species used as possible components of the diet of equines and cattle

\begin{tabular}{lccr}
\hline & L. perenne & Heather & U. gallii \\
\hline $\mathrm{C}_{23}$ & $3.2 \pm 0.55$ & $5.5 \pm 0.83$ & $0.9 \pm 0.25$ \\
$\mathrm{C}_{24}$ & $2.2 \pm 0.33$ & $3.6 \pm 0.68$ & $1.7 \pm 0.35$ \\
$\mathrm{C}_{25}$ & $11.3 \pm 1.05$ & $9.9 \pm 1.37$ & $3.3 \pm 0.62$ \\
$\mathrm{C}_{26}$ & $2.8 \pm 0.54$ & $6.4 \pm 0.73$ & $2.3 \pm 0.31$ \\
$\mathrm{C}_{27}$ & $19.3 \pm 1.51$ & $32.9 \pm 6.55$ & $20.8 \pm 2.47$ \\
$\mathrm{C}_{28}$ & $6.5 \pm 0.83$ & $17.0 \pm 6.25$ & $11.0 \pm 1.41$ \\
$\mathrm{C}_{29}$ & $78.2 \pm 6.35$ & $108.9 \pm 19.70$ & $55.4 \pm 5.54$ \\
$\mathrm{C}_{30}$ & $10.1 \pm 1.46$ & $27.2 \pm 4.38$ & $8.0 \pm 0.83$ \\
$\mathrm{C}_{31}$ & $161.4 \pm 10.69$ & $654.2 \pm 123.65$ & $106.1 \pm 10.29$ \\
$\mathrm{C}_{32}$ & $7.5 \pm 1.16$ & $54.8 \pm 5.54$ & $3.0 \pm 0.33$ \\
$\mathrm{C}_{33}$ & $93.0 \pm 9.68$ & $13.8 \pm 5.8 \pm$ & $4.4 \pm 1.34$ \\
$\mathrm{C}_{35}$ & $10.8 \pm 1.58$ & $1.5 \pm 0.23$ & $0.4 \pm 0.24$ \\
$\mathrm{C}_{36}$ & $1.4 \pm 0.14$ & $1454.2 \pm 162.51$ & $1.2 \pm 0.18$ \\
Total & $411.6 \pm 24.52$ & $1343.9 \pm 152.74$ & $218.4 \pm 20.52$ \\
Total odd-chain & $380.8 \pm 22.39$ & & $191.3 \pm 18.19$ \\
\hline
\end{tabular}

$\mathrm{C}_{33}$ in the diet composition calculations as they are normally present in high concentrations in the feeds and faeces, except for $U$. gallii which presented very low concentrations of $\mathrm{C}_{33}$. Laredo et al. (1991) considered $50 \mathrm{mg} / \mathrm{kg}$ DM to be the minimum concentration that any $n$-alkane must have to be used as a marker. However, this minimum recommended value should be carefully considered as it will depend on the analytical precision of laboratory procedures (Laredo et al., 1991; Ferreira et al., 2004).

It should be pointed out that heather showed high dispersion of the mean alkane concentrations, which could be due to different proportions of plant species of the heather group (E. umbellata, E. cinerea and C. vulgaris) or different proportions of plant parts (leaf, stem and inflorescence) in the samples collected daily, across the experiment (Dove et al., 1996; Ferreira et al., 2005).

The faecal recoveries of the alkanes $\left(\mathrm{C}_{27}, \mathrm{C}_{29}, \mathrm{C}_{31}\right.$ and $\left.\mathrm{C}_{33}\right)$ used in the estimation of diet composition are presented in Table 3. Data show that the AFR values observed in equines seem to be unrelated with the carbon chain length.

These findings are in agreement with those obtained by Ordakowski et al. (2001) who did not observe any relationship between AFR and carbon chain length in equines fed on diets composed of tall fescue (Festuca arundinacea)/alfalfa (Medicago sativa) hay and orchardgrass (Dactylis glomerata)/alfalfa hay, offered alone or supplemented with a fat/fibre feed or a starch/sugar concentrate. In contrast, Gudmundsson and Thohallsdottir (1998) in Icelandic equines fed on hays and Vouzela (2002) in donkeys fed on pastures mainly containing ryegrass (L. perenne) and white clover (Trifolium repens), observed a decrease of the AFR with the length of the carbon chain. However, this negative relationship may have resulted from the high values of faecal recovery of the alkanes with lower carbon chain length, which had very low concentrations in feeds and faeces and, for that reason, were more prone to measurement errors (Brosh et al., 2003). In fact, if we only consider the data regarding the longest odd-chain alkanes $\left(\mathrm{C}_{27}, \mathrm{C}_{29}, \mathrm{C}_{31}\right.$ and $\left.\mathrm{C}_{33}\right)$ this tendency is not 
Table 3

Mean ( \pm standard deviation) $n$-alkane faecal recoveries (AFR) observed in equines and cattle in the experimental trial

\begin{tabular}{|c|c|c|c|c|c|}
\hline \multirow[t]{2}{*}{ Treatment (T) } & \multirow[t]{2}{*}{ Alkane (A) } & \multicolumn{2}{|l|}{ Equines } & \multicolumn{2}{|l|}{ Cattle } \\
\hline & & AFR & $\mathrm{DMD}_{\mathrm{ap}}$ & AFR & $\mathrm{DMD}_{\mathrm{ap}}$ \\
\hline H1 & $\begin{array}{l}\mathrm{C}_{27} \\
\mathrm{C}_{29} \\
\mathrm{C}_{31} \\
\mathrm{C}_{33}\end{array}$ & $\begin{array}{l}0.86 \pm 0.04 \\
0.88 \pm 0.03 \\
0.87 \pm 0.04 \\
0.84 \pm 0.02\end{array}$ & $0.58 \pm 0.05$ & $\begin{array}{l}0.79 \pm 0.02 \\
0.90 \pm 0.02 \\
0.95 \pm 0.01 \\
0.98 \pm 0.02\end{array}$ & $0.59 \pm 0.01$ \\
\hline $\mathrm{H} 2$ & $\begin{array}{l}\mathrm{C}_{27} \\
\mathrm{C}_{29} \\
\mathrm{C}_{31} \\
\mathrm{C}_{33}\end{array}$ & $\begin{array}{l}1.04 \pm 0.06 \\
0.99 \pm 0.04 \\
1.02 \pm 0.02 \\
1.08 \pm 0.05\end{array}$ & $0.42 \pm 0.05$ & $\begin{array}{l}0.89 \pm 0.01 \\
0.89 \pm 0.02 \\
0.96 \pm 0.03 \\
1.14 \pm 0.03\end{array}$ & $0.50 \pm 0.02$ \\
\hline $\mathrm{H} 3$ & $\begin{array}{l}\mathrm{C}_{27} \\
\mathrm{C}_{29} \\
\mathrm{C}_{31} \\
\mathrm{C}_{33}\end{array}$ & $\begin{array}{l}0.95 \pm 0.08 \\
0.93 \pm 0.08 \\
0.93 \pm 0.07 \\
0.91 \pm 0.05\end{array}$ & $0.55 \pm 0.04$ & & \\
\hline $\mathrm{H} 4$ & $\begin{array}{l}\mathrm{C}_{27} \\
\mathrm{C}_{29} \\
\mathrm{C}_{31} \\
\mathrm{C}_{33}\end{array}$ & $\begin{array}{l}0.99 \pm 0.04 \\
0.95 \pm 0.02 \\
0.95 \pm 0.03 \\
0.99 \pm 0.05\end{array}$ & $0.39 \pm 0.02$ & & \\
\hline Effects (P) & $\begin{array}{l}\mathrm{T} \\
\mathrm{A} \\
\mathrm{T} \times \mathrm{A}\end{array}$ & $\begin{array}{l}0.0001 \\
0.6306 \\
0.6051\end{array}$ & 0.0010 & $\begin{array}{l}0.0001 \\
0.0001 \\
0.0001\end{array}$ & 0.0034 \\
\hline
\end{tabular}

$\mathrm{DMD}_{\mathrm{ap}}$ : apparent in vivo dry matter digestibility; $\mathrm{H} 1$ and $\mathrm{C} 1:$ L. perenne; $\mathrm{H} 2$ and $\mathrm{C} 2: 0.70$ L. perenne +0.30 heather; H3: $0.70 \mathrm{~L}$. perenne $+0.30 \mathrm{U}$. gallii, H4: $0.40 \mathrm{~L}$. perenne $+0.30 \mathrm{U}$. gallii +0.30 heather.

so clear. The absence of any systematic relationship between chain length and the faecal recovery was also observed in previous studies performed with other non-ruminant species such as sows (Wilson et al., 1999; Sehested et al., 1999).

In cattle, the alkane faecal recoveries increased with the increase of the carbon chain length. These results are consistent with those reported in previous studies performed in cattle (Hendricksen et al., 2002, 2003; Brosh et al., 2003; Oliván et al., 2007) and in other ruminant species, like sheep (Mayes et al., 1986; Elwert et al., 2004) and goats (Brosh et al., 2003). The comparison of alkane recoveries obtained in equines and in cattle (Table 3) indicated that the $n$-alkanes behave differently in the gastro-intestinal tract of ruminant and non-ruminant species.

Previous studies carried out with goats (Ferreira et al., 2005) and sheep (Ferreira et al., 2006) fed on the same vegetation components used in this trial, indicated a effect of diet composition and its digestibility on alkane faecal recoveries. It should be noted that this effect can be specific for each situation, depending on the particular species comprising the diets (Ferreira et al., 2006).

In the present study, the results indicated that the faecal recoveries were affected $(\mathrm{P}<0.001)$ by diet composition (Table 3 ) in both animal species, showing a general tendency for higher faecal recoveries in diets with lower digestibility. The effect of diet digestibility on alkane faecal recoveries was only evaluated in equines as the range of diets digestibility 

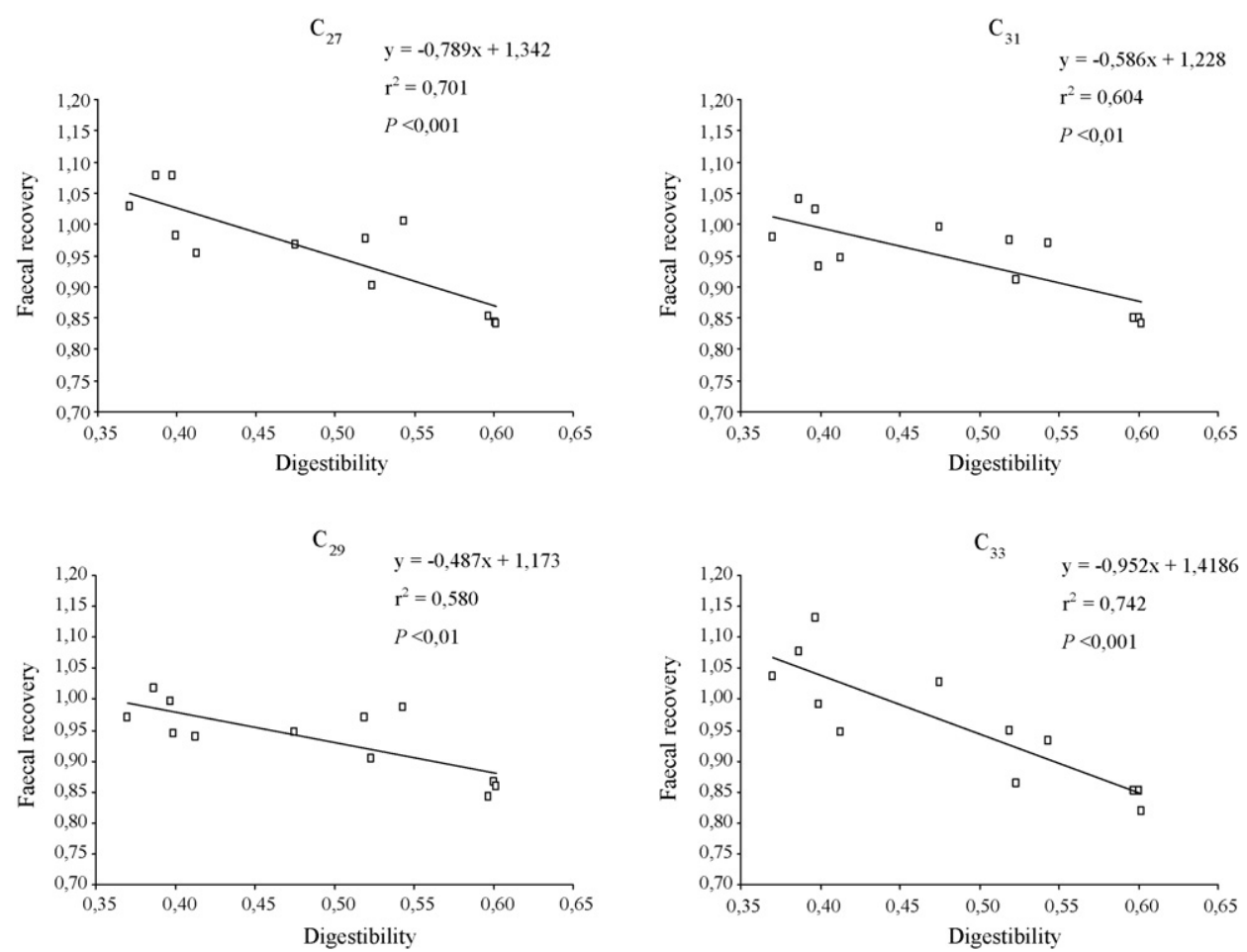

Fig. 1. Relationship between diet digestibility and faecal recovery of the $n$-alkane $C_{27}, C_{29}, C_{31}$ and $C_{33}$ observed in the equine treatments.

in cattle was small ( 0.50 to 0.59 ). Fig. 1 illustrates the relationship between diet digestibility and the faecal recovery of the alkanes $\left(\mathrm{C}_{27}, \mathrm{C}_{29}, \mathrm{C}_{31}\right.$ and $\left.\mathrm{C}_{33}\right)$ observed in equines.

As expected, the data on the digestibility of the experimental diets showed that the inclusion of a less digestible feed (gorse and heather) in the diet resulted in a decrease of the whole diet digestibility. These results and others obtained in our laboratory with goats (Ferreira et al., 2005) and sheep (Ferreira et al., 2006), and those observed in brushtail possum (Trichosurus vulpecula) by Monks et al. (2005) suggest that a decrease in the diet digestibility can result in a increase of the recovery of the alkane markers in the faeces.

The effect of applying different faecal recoveries (R1, R2 and R3) to the alkane faecal concentrations on the accuracy of the estimates of diet composition was distinct for both animal species (Tables 4 and 5). In equines, this effect did not have a significant impact on the estimates of all diet components. In contrast, in cattle this effect was significant for all dietary feeds.

The estimates obtained by each set of faecal recoveries (R1, R2 and R3) were individually compared to the known values (those statistically different $(\mathrm{P}<0.05)$ are marked in bold in Tables 4 and 5). In general, for both animal species the best estimates were obtained when faecal concentrations were adjusted for incomplete faecal recovery using the mean diet faecal recoveries (R2). In equines the use of uncorrected alkane faecal concentrations 
Table 4

Effect of using different methods of alkane faecal recovery adjustments (R1, R2 and R3) on diet composition estimates obtained in the equine groups

\begin{tabular}{|c|c|c|c|c|c|c|c|c|c|c|c|c|}
\hline & \multicolumn{3}{|l|}{ H1 } & \multicolumn{3}{|l|}{$\mathrm{H} 2$} & \multicolumn{3}{|l|}{$\mathrm{H} 3$} & \multicolumn{3}{|l|}{ H4 } \\
\hline & L. perenne & Heather & U. gallii & L. perenne & Heather & U. gallii & L. perenne & Heather & U. gallii & L. perenne & Heather & U. gallii \\
\hline R1 & 0.967 & 0.003 & 0.030 & 0.646 & 0.354 & 0 & 0.684 & 0.003 & 0.313 & 0.509 & 0.306 & 0.185 \\
\hline R2 & 0.979 & 0.008 & 0.013 & 0.604 & 0.306 & 0.090 & 0.708 & 0.003 & 0.289 & 0.371 & 0.302 & 0.328 \\
\hline R3 & 0.956 & 0.002 & 0.042 & 0.650 & 0.341 & 0.009 & 0.675 & 0.002 & 0.323 & 0.472 & 0.300 & 0.228 \\
\hline $\mathrm{P}$ & 0.7757 & 0.1964 & 0.6344 & 0.4978 & 0.1109 & 0.1143 & 0.1205 & 0.7965 & 0.1433 & 0.4382 & 0.6363 & 0.4192 \\
\hline SEM & 0.023 & 0.002 & 0.021 & 0.029 & 0.014 & 0.028 & 0.010 & 0.001 & 0.011 & 0.075 & 0.004 & 0.073 \\
\hline
\end{tabular}

H1: L. perenne; $\mathrm{H} 2: 0.70$ L. perenne +0.30 heather; $\mathrm{H} 3: 0.70$ L. perenne +0.30 U. gallii; $\mathrm{H} 4: 0.40$ L. perenne +0.30 U. gallii +0.30 heather; R1: without recovery correction; R2: corrected with treatment mean AFR; R3: corrected with study mean AFR; SEM: standard error of mean. Values in the same column for each group with different letters are significantly different $(\mathrm{P}<0.05)$. 
Table 5

Effect of using different methods of alkane faecal recovery adjustments (R1, R2 and R3) on diet composition estimates obtained in the cattle groups

\begin{tabular}{|c|c|c|c|c|c|c|}
\hline & \multicolumn{3}{|l|}{$\mathrm{C} 1$} & \multicolumn{3}{|l|}{$\mathrm{C} 2$} \\
\hline & L. perenne & Heather & U. gallii & L. perenne & Heather & U. gallii \\
\hline $\mathrm{R} 1$ & $0.969^{a b}$ & $0.031^{\mathrm{a}}$ & $0^{\mathrm{b}}$ & $0.489^{b}$ & $0.511^{\mathrm{a}}$ & 0 \\
\hline $\mathrm{R} 2$ & $0.990^{\mathrm{a}}$ & $0.002^{\mathrm{b}}$ & $0.008^{\mathrm{b}}$ & $0.661^{\mathrm{a}}$ & $0.299^{\mathrm{d}}$ & 0.040 \\
\hline $\mathrm{R} 3$ & $0.913^{c}$ & $0.003^{\mathrm{b}}$ & $0.084^{\mathrm{a}}$ & $0.654^{\mathrm{a}}$ & $0.346^{c}$ & 0 \\
\hline $\mathrm{P}$ & 0.0001 & 0.0001 & 0.0001 & 0.0001 & 0.0001 & 0.0497 \\
\hline SEM & 0.005 & 0.002 & 0.006 & 0.011 & 0.004 & 0.010 \\
\hline
\end{tabular}

$\mathrm{C} 1$ : L. perenne; $\mathrm{C} 2$ : 0.70 L. perenne +0.30 heather; $\mathrm{R} 1$ : without recovery correction; $\mathrm{R} 2$ : corrected with treatment mean AFR; R3: corrected with study mean AFR; SEM: standard error of mean. Values in the same column with different letters are significantly different $(\mathrm{P}<0.05)$.

or concentrations corrected by the study mean faecal recoveries also produced accurate estimates of diet composition, except for L. perenne and heather in the $\mathrm{H} 2$ treatment.

In these cases there was an overestimation of the plant species with higher concentration of long carbon-chain $n$-alkanes. These results showed that correction procedures are unnecessary when recovery is unaffected by chain length due to the importance of the relative concentration of the alkanes, rather than the absolute recoveries (Dove and Mayes, 2005).

The use of uncorrected faecal alkane concentrations in cattle (R1) led to the overestimation of the feed (heather) with higher concentration of long carbon-chain $n$-alkanes $\left(\mathrm{C}_{29}\right.$ to $\mathrm{C}_{33}$ ). Therefore, in the case of cattle we needed to correct the alkane faecal concentrations for their incomplete faecal recovery in order to avoid bias in the diet composition estimates, as suggested in previous studies conducted with cattle (Brosh et al., 2003), sheep (Elwert et al., 2004; Ferreira et al., 2006) and goats (Ferreira et al., 2005).

The same overestimation of heather was observed when using alkane faecal concentrations adjusted with the mean faecal recoveries across all diets (R3). However, this was a result of a discrepancy between these recovery values (R3) and the actual ones. It is obvious that the best agreement between the known and estimated proportions of the vegetation components would be that obtained using alkane faecal concentrations corrected with the recoveries of each animal. However, in grazing studies this determination is impracticable, leading to the currently utilized sets of faecal recovery obtained in studies with animals housed in metabolic cages and fed on different diets.

As referred by Ferreira et al. (2006) for sheep, the utilization of alkane faecal concentrations corrected with the mean recovery of the dietary treatment (R2) or mean alkane faecal recoveries across all experimental diets $(\mathrm{R} 3)$ in the diet composition calculations will likely decrease the accuracy of the estimates. The degree to which this decrease may occur will depend on the deviation of these sets of faecal recovery from the actual ones, as a result of the individual variability between animals within the same dietary treatment, as well as due to variation between diets (diet composition effect).

In fact, Valiente et al. (2003) observed in Rasa Aragonesa ewes fed on different proportions of barley grain and straw that the variation between individuals accounted for 0.85 of total variability. The results obtained in goats (Ferreira et al., 2005) and sheep (Ferreira et al., 2006), showed the relationship between individual variability and alkane chain length, 
being higher for the alkanes $\mathrm{C}_{25}$ to $\mathrm{C}_{28}$ ( 0.17 and 0.31 in goats and sheep, respectively) when compared to those obtained for the alkanes $C_{29}$ to $C_{33}(0.10$ and 0.19 in goats and sheep, respectively).

As stated before, the diet composition effect can be specific for each situation, depending on the particular species comprising the diets (Ferreira et al., 2006). There are studies indicating a diet effect on the alkane faecal recoveries while others suggest the absence of such effect. Hendricksen et al. (2002) observed a high variation of alkane faecal recoveries between diets composed of tropical grass and lucerne hays offered to steers. Opposite results were obtained in sheep fed on different proportions of barley grain and straw (Valiente et al., 2003) and sheep fed on pelleted alfalfa and ground wheat grain (Elwert et al., 2004).

\section{Conclusions}

The results obtained in this study show that the $n$-alkane markers can be used to estimate diet composition of equines and cattle fed on herbaceous and woody species. The results suggest that the application of this technique in cattle should be preceded by a previous adjustment of alkane faecal concentrations to incomplete faecal recovery. In contrast, diet composition of equines can be accurately estimated, even without a previous correction of the alkane faecal concentrations.

\section{Acknowledgments}

L.M.M. Ferreira was funded by the Portuguese Foundation for Science and Technology (Doctoral grant SFRH/BD/16833/2004). The authors would like to thank to the Carbayal Research Station staff for their help in the field work and to M. Mocha, M.J. Martínez and C.S. Moura for collaboration in analytical procedures. The financial support of project AGL2003-05342/GAN by Comisión Interministerial de Ciencia y Tecnología (CICYT) is also gratefully acknowledged.

\section{References}

Aldezabal, A., 2001. El sistema de pastoreo del Parque Nacional de Ordesa y Monte Perdido (Pirineo Central, Aragón). Interacción entre la vegetación supraforestal y los grandes herbívoros, 28. Publicaciones del Consejo de Protección de la Naturaleza de Aragón, Zaragoza.

Association of Official Analytical Chemists, 1990. Official Methods of Analysis, 14th ed., AOAC, Washington, DC.

Brosh, A., Henkin, Z., Rothman, S.J., Aharoni, Y., Orlov, A., Arieli, A., 2003. Effects of faecal $n$-alkane recovery in estimates of diet composition. J. Agric. Sci. 140, 93-100.

Dove, H., Mayes, R.W., 2005. Using $n$-alkanes and other plant wax components to estimate intake, digestibility and diet composition of grazing/browsing sheep and goats. Small Rum. Res. 59, 123-139.

Dove, H., Mayes, R.W., Freer, M., 1996. Effects of species, plant part, and plant age on the $n$-alkane concentrations in the cuticular wax of pasture plants. Aust. J. Agric. Res. 47, 1333-1347.

Elwert, C., Kluth, H., Rodehutscord, M., 2004. Effect of variable intake of alfalfa and wheat on faecal alkane recoveries and estimates of roughage intake in sheep. J. Agric. Sci. 142, 213-223. 
Ferreira, L.M.M., Oliván, M., Celaya, R., Garcia, U., Rodrigues, M.A.M., Osoro, K., 2006. The use of the alkane technique to estimate diet selection of sheep grazing grass-clover/heather-gorse vegetation communities. J. Sci. Food Agric. 87, 274-285.

Ferreira, L.M.M., Oliván, M., Rodrigues, M.A.M., Garcia, U., Osoro, K., 2005. Validation of the alkane technique to estimate diet selection of goats grazing heather-gorse vegetation communities. J. Sci. Food Agric. 85, 1636-1646.

Ferreira, L.M.M., Oliván, M., Rodrigues, M.A.M., Osoro, K., Dove, H., Dias-da-Silva, A., 2004. Estimation of feed intake by cattle using controlled-release capsules containing $n$-alkanes or chromium sesquioxide. J. Agric. Sci. 142, 225-234.

Gudmundsson, O., Thohallsdottir, A.G., 1998. Evaluation of $n$-alkanes for intake and digestibility determination in horses. In: Proceedings of the IXth European Intake Workshop, North Wyke, Devon, UK, pp. 1-4.

Hendricksen, R.E., Gazzola, C., Reich, M.M., Roberton, R.F., Reid, D.J., Hill, R.A., 2003. Using molasses as an alternative to controlled release devices for administering $n$-alkane markers to cattle. Anim. Sci. 76, 471-480.

Hendricksen, R.E., Reich, M.M., Roberton, R.F., Reid, D.J., Gazzola, C., Rideout, J.A., Hill, R.A., 2002. Estimating the voluntary intake and digestibility of buffel-grass and lucerne hays offered to Brahman-cross cattle using n-alkanes. Anim. Sci. 74, 567-577.

JMP, 2003. User's Guide: Statistical Discovery Software, Version 5. SAS Inst. Inc., Cary, NC.

Laredo, M.A., Simpson, G.D., Minson, D.J., Orpin, C.G., 1991. The potential for using $n$-alkanes in tropical forages as a marker for determination of dry matter intake by grazing ruminants. J. Agric. Sci. 117, $355-361$.

Lechner-Doll, M., Hume, I.D., Hofmann, R.R., 1995. Comparison of herbivore forage selection and digestion. In: Journet, M., Grenet, E., Farce, M.-H., Theriez, M., Demarquilly, C. (Eds.), Recent developments in the nutrition of herbivores. Proceedings of the IVth International Symposium on the Nutrition of Herbivores. INRA Editions, Paris, pp. 231-248.

Mayes, R.W., Lamb, C.S., Colgrove, P.M., 1986. The use of dosed and herbage $n$-alkanes as markers for the determination of herbage intake. J. Agric. Sci. 107, 161-170.

Monks, A., Payton, I., Efford, M., 2005. Validation of the $n$-alkane technique for estimating diet composition, digestibility and dry matter intake in the brushtail possum (Trichosurus vulpecula). Wildlife Res. 32, 321-331.

Oliván, M., Dove, H., Mayes, R.W., Hoebee, S.E., 1999. Recent developments in the use of alkanes and other plant wax components to estimate intake and diet composition in herbivores. Revista Portuguesa de Zootecnia VI 1, 1-26.

Oliván, M., Ferreira, L.M.M., Celaya, R., Osoro, K., 2007. Accuracy of the $n$-alkane technique for intake estimates in beef cattle at different sampling times and feeding levels. Lives. Sci. 106, 28-40.

Oliván, M., Osoro, K., 1997. Utilización de la técnica de los $n$-alcanos en estudios de ingestión y selección de dieta de los rumiantes en pastoreo: Revisión. Información Técnica Económica Agraria 93A, 193-208.

Oliván, M., Osoro, K., 1999. Effect of temperature on alkane extraction from faeces and herbage. J. Agric. Sci. 132, 305-312.

Ordakowski, A.L., Kronfeld, D.S., Holland, J.L., Hargreaves, B.J., Gay, L.S., Harris, P.A., Dove, H., Sklan, D., 2001. Alkanes as internal markers to estimate digestibility of hay or hay plus concentrate diets in horses. J. Anim. Sci. 79, 1516-1522.

Osoro, K., Garcia, U., Jáuregui, B.M., Ferreira, L.M.M., Oliván, M., Celaya, R., 2005. Conducta de pastoreo y variaciones de peso de los herbívoros domésticos en un brezal-tojal parcialmente mejorado. In: Osoro, K., Argamendia, A., Larraceleta, A. (Eds.), Producciones agroganaderas: gestión eficiente y conservación del médio natural (Volumen 1). XLV Reunión Científica de la Sociedad Española para el Estudio de los Pastos. Gijón, pp. 252-258.

Osoro, K., Garcia, U., Jáuregui, B.M., Ferreira, L.M.M., Rook, A.J., Celaya, R., in press. Diet components, its nutrient content and live weight changes and productivity of two breeds of goats grazing on heathlands. Anim. Sci.

Osoro, K., Oliván, M., Martínez, A., García, U., Celaya, R., 2003. Diet selection and live weight changes in domestic ruminants grazing on heathland vegetation with areas of improved pastures. In: Proceedings of the VI International Symposium on the Nutrition of Herbivores, Tropical and Subtropical Agroecosystems vol. 3, no. 1-3, pp. 491-494.

Rook, A.J., Dumont, B., Isselstein, J., Osoro, K., WallisDeVries, M.F., Parente, G., Mills, J., 2004. Matching type of livestock to desired biodiversity outcomes in pastures - a review. Biol. Conserv. 119, 137-150. 
Salt, C.A., Mayes, R.W., Colgrove, P.M., Lamb, C.S., 1994. The effects of season and diet composition on the radiocaesium intake by sheep grazing on heather moorland. J. Appl. Ecol. 31, 125-136.

Sehested, J., Breinhild, K.K., Søegaard, K., Vognsen, L., Hansen, H.H., Fernández, J.A., Danielsen, V., Kristensen, V.F., 1999. Use of $n$-alkanes to estimate grass intake and digestibility in sows. In: Dove, H., Coleman, S.W. (Eds.), Nutritional Ecology of Herbivores. Satellite Symposium: Emerging techniques for studying the nutrition of free ranging herbivores. San Antonio, Texas, USA (CD-ROM).

Valiente, O.L., Delgado, P., de Vega, A., Guada, J.A., 2003. Validation of the $n$-alkane technique to estimate intake, digestibility, and diet composition in sheep consuming mixed grain-roughage diets. Aust. J. Agric. Res. 54, 693-702.

Van Soest, P.J., Robertson, J.B., Lewis, B.A., 1991. Methods for dietary fiber, neutral detergent fiber, and nonstarch polysaccharides in relation to animal nutrition. J. Dairy Sci. 74, 3583-3597.

Vouzela, C.F.M., 2002. Validação dos $n$-alcanos como marcadores em herbívoros. PhD Thesis, University of Azores, Angra do Heroísmo.

Wilson, H., Sinclair, A.G., Hovell, F.D.DeB., Mayes, R.W., Edwards, S.A., 1999. Validation of the $n$-alkane technique for measuring herbage intake in sows. In: Proceedings of the British Society of Animal Science, p. 171 . 